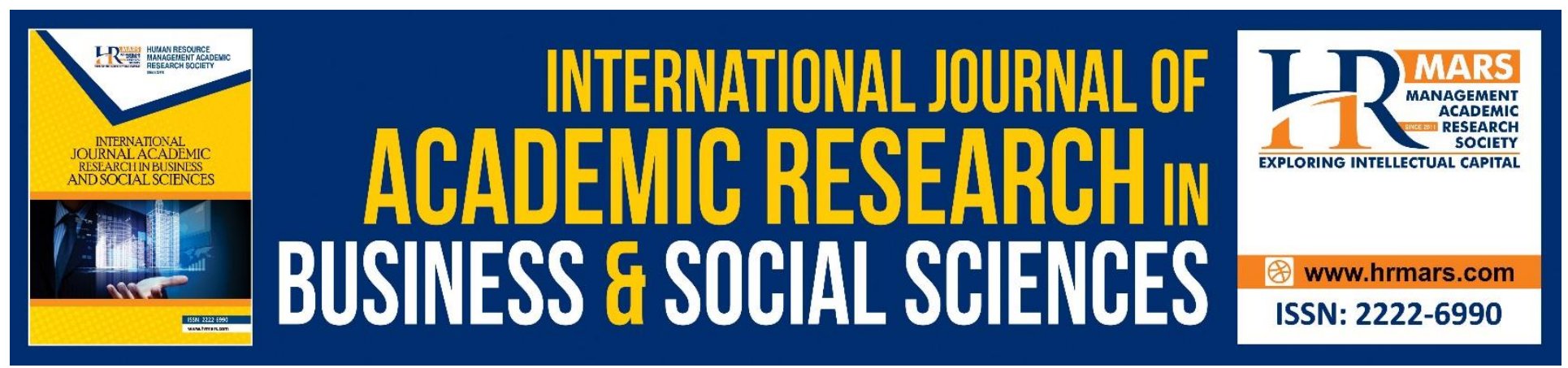

\title{
The Proficiency in the Complete Jawi Spelling System (CJSS) Among Islamic Studies Teachers in Malacca
}

Naquiah Nahar, Jimaain Safar, Aminudin Hehsan, Juhazren Junaidi

To Link this Article: http://dx.doi.org/10.6007/IJARBSS/v8-i12/5449

DOI: $10.6007 /$ IJARBSS/v8-i12/5449

Received: 05 Dec 2018, Revised: 24 Dec 2018, Accepted: 11 Jan 2019

Published Online: 13 Jan 2019

In-Text Citation: (Nahar, Safar, Hehsan, \& Junaidi, 2018)

To Cite this Article: Nahar, N., Safar, J., Hehsan, A., \& Junaidi, J. (2018). The Proficiency in the Complete Jawi Spelling System (CJSS) Among Islamic Studies Teachers in Malacca. International Journal of Academic Research in Business and Social Sciences, 8(12), 2403-2417.

Copyright: (C) 2018 The Author(s)

Published by Human Resource Management Academic Research Society (www.hrmars.com)

This article is published under the Creative Commons Attribution (CC BY 4.0) license. Anyone may reproduce, distribute, translate and create derivative works of this article (for both commercial and non-commercial purposes), subject to full attribution to the original publication and authors. The full terms of this license may be seen at: $\underline{\text { http://creativecommons.org/licences/by/4.0/legalcode }}$

Vol. 8, No. 12, 2018, Pg. 2403 - 2417

Full Terms \& Conditions of access and use can be found at http://hrmars.com/index.php/pages/detail/publication-ethics 


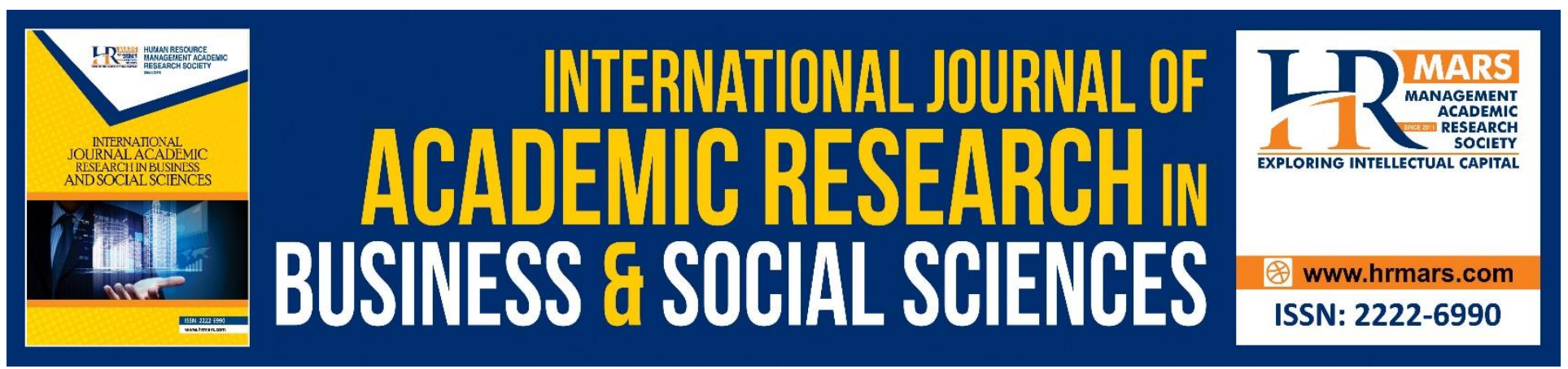

\title{
The Proficiency in the Complete Jawi Spelling System (CJSS) Among Islamic Studies Teachers in Malacca
}

\author{
Naquiah Nahara, Jimaain Safar ${ }^{\mathrm{b}}$, Aminudin Hehsan, \\ Juhazren Junaidid \\ ${ }^{a-b}$ Academy of Islamic Civilization (ICA), Universiti Teknologi Malaysia \\ ${ }^{c-d}$ Center of Research Fiqh Science and Technology (CFiRST), Universiti Teknologi Malaysia \\ Malaysia
}

\begin{abstract}
The effectiveness of teaching practice is closely related to the teachers' proficiency on the contents of the subject taught. For Jawi subject, the contents refer to the teachers' proficiency on the Complete Jawi Spelling System (CJSS). The teachers' proficiency of CJSS will highly affect the students' proficiency in Jawi reading and writing and their knowledge in Islamic Studies subject indirectly. However, the study found that the students' proficiency in Jawi is still low and moderate. The shortcomings were found to be stemmed from poor proficiency in the contents of CJSS among Islamic Studies teachers. Thus, this study aims to examine the level of knowledge and skill acquisition of CJSS of Islamic Studies teachers in Malacca. This quantitative research used descriptive statistics, which were percentage and mean value to report the finding. The questionnaire used a five-point Likert scale conducted on 217 respondents. The results showed that the proficiency level of CJSS of Islamic Studies teachers was high (mean $=4.074, \mathrm{sd}=0.350$ ). In general, it can be concluded that the Islamic Studies teachers in Malacca have mastered the contents of Jawi lessons, which was CJSS.

Keywords: Teachers' Proficiency, Jawi Lessons, Subject Content, Cjss, Islamic Studies Teachers
\end{abstract}

\section{INTRODUCTION}

Jawi lesson was one of the components contained in Islamic Studies subject. Jawi lesson was included in the Integrated Curriculum for Primary Schools (ICPS) in 2003 with a special emphasis on Jawi reading and writing skills (Abd Hamid \& Abdullah, 2009; The Ministry of Education, 2003; Mohamad @ Mohd Nor, 2013). The Ministry of Education has also decided that all Islamic Studies teachers across the country should use the Complete Jawi Spelling System (CJSS) that have been outlined by the Dewan Bahasa and Pustaka (DBP) during Jawi lessons in classroom. This indirectly indicated that the Islamic Studies teachers must have in-depth knowledge and skills to master the CJSS system well because without mastering the contents of the subjects taught, the delivery of knowledge could not occur optimally. 


\section{STATEMENT OF THE PROBLEM}

The ability of students to master Jawi reading and writing was very important because it was a factor that affected their understanding and proficiency in Islamic Studies (Che Man, 2007). To ensure that students were able to master Jawi reading and writing skills well, it depended on the mastery of the contents of the Complete Jawi Spelling System (CJSS) by the teachers who taught that subject. This was because teachers who had deep knowledge of the subjects they taught would be able to convey knowledge effectively to students. Teachers who did not have deep knowledge on the other hand, would have difficulties in delivering lessons comprehensively and were unable to produce students who could master the skills taught.

However, previous studies found that the students' proficiency in Jawi was at an alarming rate (Ali \& Abdullah, 2015; Abd Hamid \& Abdullah, 2009; Mohamad, 2007) and poor Jawi proficiency occured not only among primary school pupils (Suhid et al., 2008; Haron, 2008; Mohd Hassan Abdullah et al., 2010) and secondary school students (Nik Yaacob, 2007), but also among students in higher education (Jemali, 2008) and religious school students (Abd Hamid \& Abdullah, 2009).

Based on previous studies that was conducted to identify the causes of these weaknesses, the teaching aspect was one of the factors that led to students' poor proficiency in Jawi. This factor was also closely related to the level of Jawi knowledge and skills among teachers who taught Jawi. The findings by Ali (2011 \& 2012) and Abdullah (2014) for example showed that the proficiency of Jawi spelling among teachers-to-be were low and moderate. These findings were consistent with the study by Bahrun (2011) conducted on 265 trainee teachers at one of the Institute of Education which showed that $57.2 \%$ of them failed to master Jawi spelling using the correct Complete Jawi Spelling System (CJSS).

These shortcomings were serious and should not be taken lightly by the Islamic Studies teachers across the country as they were the group who was responsible for teaching Jawi to students. This phenomenon was worrying because of the lack of Jawi proficiency among Islamic Studies teachers that would likely giving inaccurate facts to students during teaching and learning sessions. This situation was not supposed to happen because the teachers should have deep knowledge of the contents of the lessons (Syarifuddin \& Halim, 2017; Nor \& Mahamod, 2014; Hashim \& Phang, 2013). Hence, this study was conducted to examine the level of the content mastery of Islamic Studies teachers in Jawi and their skills in the Complete Jawi Spelling System (CJSS).

\section{OBJECTIVES OF THE STUDY}

This study aims to achieve the following objectives:

1. To identify the profile of the Islamic Studies teachers who have taught Jawi lessons.

2. To evaluate the proficiency level of content knowledge and the Complete Jawi Spelling System (CJSS) skills among Islamic Studies teachers in Malacca. 


\section{METHODOLOGY}

This study was a quantitative research using survey to get feedback on the phenomenon being studied. Sampling technique used in this study was simple random sampling which involved 217 Islamic Studies teachers from Melaka Tengah district based on Sample Size Determination Table (Krejcie \& Morgan, 1970). The questionnaire and test were instruments used for this study to evaluate the proficiency level of Islamic Studies teachers on the Complete Jawi Spelling System (CJSS). In short, the survey questionnaire consisted of three parts which were:

Table 1: Research Instruments

\begin{tabular}{lll}
\hline Part & Research Instrument & Item \\
\hline A & Questionnaire & $\begin{array}{l}\text { Teacher's demographic data (age, gender, academic } \\
\text { qualification, professional qualification and teaching } \\
\text { experience) } \\
\text { Knowledge on the e/wa_method, Derlung rule, } \\
\text { Homograph dan numbering technique }\end{array}$ \\
C & Test & $\begin{array}{l}\text { Skills in changing the words into Jawi according to the } \\
\text { CJSS method. }\end{array}$ \\
\hline
\end{tabular}

This questionnaire used a five-point Likert scale. The scores included Strongly Disagree (SD) with point 1, Disagree (D) with point 2, Less Agree (LA) with point 3, Agree (A) with point 4 and Strongly Agree (SA) with point 5 . The reliability of this study was measured using the internal consistency through Cronbach Alpha and the reliability of the construct of knowledge on CJSS obtained the value of 0.913. This value was considered high because according to George \& Mallery (2006), the coefficient alpha value of 0.8 was considered good while the coefficient alpha value above 0.9 was considered excellent.

\section{ANALYSIS AND FINDING}

\section{Teacher's Demographic Data}

The analysis of this study used The Statistical Package for the Social Sciences (IBBM SPSS) program version 21.0. Based on the sample distribution as shown in Table 2, 159 respondents (73.3\%) were women while only 58 (26.7\%), were men.

Table 2: Sample Distribution based on Gender

\begin{tabular}{lll}
\hline Gender & Frequency & Percentage (\%) \\
\hline Male & 58 & 26.7 \\
Female & 159 & 73.3 \\
Total & 217 & 100 \\
\hline
\end{tabular}

The results in Table 3 show the highest academic qualification of the respondents of this study. A total of 180 respondents (82.9\%) were Islamic Studies teachers under graduate category who have a Bachelor's and Master's degree. For non-graduate category, 37 of the respondents either have a Diploma, STPM or SPM (11.1\%). 
INTERNATIONAL JOURNAL OF ACADEMIC RESEARCH IN BUSINESS AND SOCIAL SCIENCES

Vol. 8, No. 12, Dec, 2018, E-ISSN: 2222-6990 @ 2018 HRMARS

Table 3: Sample Distribution based on Academic Qualification

\begin{tabular}{lll}
\hline Academic Qualification & Frequency & Percentage (\%) \\
\hline Graduate & 180 & 82.9 \\
Non-Graduate & 37 & 17.1 \\
Total & 217 & 100 \\
\hline
\end{tabular}

Referring to Table 4, out of 217 respondents, 86 of them (39.6\%) have a Diploma of Education as their professional qualification. Bachelor of Education recorded the second highest distribution of professional qualification, which were 73 respondents (33.6\%) and the Certificate of Education recorded the lowest distribution which were 58 respondents $(26.7 \%)$.

Table 4: Sample Distribution based on Professional Qualification

\begin{tabular}{lll}
\hline Professional Qualification & Frequency & Percentage (\%) \\
\hline Bachelor of Education & 73 & 33.6 \\
Diploma of Education & 86 & 39.6 \\
Certificate of Education & 58 & 26.7 \\
Total & 217 & 100 \\
\hline
\end{tabular}

For the sample distribution based on Jawi teaching experience, category 1-5 years reported the highest value, which were 68 respondents (31.3\%). For 6-10 years category, it recorded the second highest value, which were 59 respondents (27.2\%) and for the category of 11-15 years were 54 respondents $(24.9 \%)$. While the remaining 36 respondents $(16.6 \%)$ were for the category of more than 15 years of teaching experience. The sample distribution based on Jawi teaching experience is shown in Table 5.

Table 5: Sample Distribution based on Jawi Teaching Experience

\begin{tabular}{lll}
\hline Jawi Teaching Experience & Frequency & Percentage \\
\hline 1-5 years & 68 & 31.3 \\
$6-10$ years & 59 & 27.2 \\
$11-15$ years & 54 & 24.9 \\
More than 15 years & 36 & 16.6 \\
Total & 217 & 100 \\
\hline
\end{tabular}

Based on the discussion on the demographics of the respondents, the majority of the respondents were women, which were $73.3 \%$. In terms of the highest academic qualification, the majority of the respondents $(82.9 \%)$ were graduate teachers while the highest professional qualification were Diploma holders in teaching which were $39.6 \%$. In terms of teaching experience, $31.3 \%$ of the respondents have been teaching Jawi for 1 to 5 years. 
INTERNATIONAL JOURNAL OF ACADEMIC RESEARCH IN BUSINESS AND SOCIAL SCIENCES

Vol. 8, No. 12, Dec, 2018, E-ISSN: 2222-6990 @ 2018 HRMARS

The Knowledge of Complete Jawi Spelling System (CJSS)

The detail distribution of the finding for Islamic Studies teachers' understanding on CJSS was shown in Table 6. The overall mean for Jawi teaching practice was high (mean $=4.074$, sd $=0.350$ ).

Table 6: The Mean Score Distribution on the Knowledge of Complete Jawi Spelling System (CJSS)

\begin{tabular}{|c|c|c|c|c|c|c|c|c|}
\hline $\begin{array}{l}\text { Cod } \\
\text { e }\end{array}$ & Aspect/Item & SD & D & LA & A & SA & $\begin{array}{l}\text { MEA } \\
\mathbf{N}\end{array}$ & SD \\
\hline & _e/wa Method & & & & & & & \\
\hline C1 & $\begin{array}{l}\text { The word ديوان belongs to } \\
\text { _e/wa_method. }\end{array}$ & $\begin{array}{c}1 \\
(0.5 \%)\end{array}$ & $\begin{array}{c}5 \\
(2.3 \%)\end{array}$ & $\begin{array}{c}11 \\
(5.1 \%)\end{array}$ & $\begin{array}{c}155 \\
(71.4 \\
\%)\end{array}$ & $\begin{array}{l}45 \\
(20.7 \\
\%)\end{array}$ & $\begin{array}{c}4.09 \\
7\end{array}$ & $\begin{array}{c}0.61 \\
9\end{array}$ \\
\hline $\mathrm{C} 2$ & $\begin{array}{l}\text { The word ليوتcannot be } \\
\text { categorised in _e/wa_ } \\
\text { method. }\end{array}$ & $\begin{array}{c}30 \\
(13.8 \\
\%)\end{array}$ & $\begin{array}{c}32 \\
(14.7 \\
\%)\end{array}$ & $\begin{array}{c}32 \\
(14.7 \\
\%)\end{array}$ & $\begin{array}{c}95 \\
(43.8 \\
\%)\end{array}$ & $\begin{array}{c}28 \\
(12.9 \\
\%)\end{array}$ & $\begin{array}{c}3.27 \\
2\end{array}$ & $\begin{array}{c}1.26 \\
0\end{array}$ \\
\hline C3 & $\begin{array}{l}\text { The word 'tewas' is spelled as } \\
\text { تيواس according to CJSS. }\end{array}$ & $\begin{array}{c}4 \\
(1.8 \%)\end{array}$ & $\begin{array}{c}9 \\
(4.1 \%)\end{array}$ & $\begin{array}{c}20 \\
(9.2 \%)\end{array}$ & $\begin{array}{c}139 \\
(64.1 \\
\%)\end{array}$ & $\begin{array}{c}45 \\
(20.7 \\
\%)\end{array}$ & $\begin{array}{c}3.97 \\
7\end{array}$ & $\begin{array}{c}0.79 \\
6\end{array}$ \\
\hline C4 & $\begin{array}{l}\text { I explain to students that the } \\
\text { word حيوان does not meet the } \\
\text { conditions of _e/wa_ } \\
\text { method. }\end{array}$ & $\begin{array}{c}10 \\
(4.6 \%)\end{array}$ & $\begin{array}{c}19 \\
(8.8 \%)\end{array}$ & $\begin{array}{c}31 \\
(14.3 \\
\%)\end{array}$ & $\begin{array}{c}126 \\
(58.1 \\
\%)\end{array}$ & $\begin{array}{c}31 \\
(14.3 \\
\%)\end{array}$ & $\begin{array}{c}3.68 \\
7\end{array}$ & $\begin{array}{c}0.97 \\
8\end{array}$ \\
\hline C5 & $\begin{array}{l}\text { I explain to students that the } \\
\text { condition of _e/wa_ method } \\
\text { is where the first syllable } \\
\text { must have an e- taling vowel. }\end{array}$ & $\begin{array}{c}4 \\
(1.8 \%)\end{array}$ & $\begin{array}{c}14 \\
(6.5 \%)\end{array}$ & $\begin{array}{c}39 \\
(18.0 \\
\%)\end{array}$ & $\begin{array}{c}150 \\
(69.1 \\
\%)\end{array}$ & $\begin{array}{c}10 \\
(4.6 \%)\end{array}$ & $\begin{array}{c}3.68 \\
2\end{array}$ & $\begin{array}{c}0.74 \\
2\end{array}$ \\
\hline C6 & $\begin{array}{l}\text { I explain to students } \\
\text { that_e/wa_ method } \\
\text { maintains alif vowel as the } \\
\text { sound symbol [a]. }\end{array}$ & $\begin{array}{c}6 \\
(2.8 \%)\end{array}$ & $\begin{array}{c}12 \\
(5.5 \%)\end{array}$ & $\begin{array}{c}40 \\
(18.4 \\
\%)\end{array}$ & $\begin{array}{c}142 \\
(65.4 \\
\%)\end{array}$ & $\begin{array}{c}17 \\
(7.8 \%)\end{array}$ & $\begin{array}{c}3.70 \\
1\end{array}$ & $\begin{array}{c}0.80 \\
4\end{array}$ \\
\hline & Derlung Rule & & & & & & & \\
\hline $\mathrm{C7}$ & $\begin{array}{l}\text { The word بيدارا is included in } \\
\text { Derlung Rule. }\end{array}$ & $\begin{array}{c}6 \\
(2.8 \%)\end{array}$ & $\begin{array}{c}6 \\
(2.8 \%)\end{array}$ & $\begin{array}{c}20 \\
(9.2 \%)\end{array}$ & $\begin{array}{c}149 \\
(68.7 \\
\%)\end{array}$ & $\begin{array}{c}36 \\
(16.6 \\
\%)\end{array}$ & $\begin{array}{c}3.93 \\
6\end{array}$ & $\begin{array}{c}0.78 \\
5\end{array}$ \\
\hline C8 & $\begin{array}{l}\text { Derlung Rule uses alif vowel } \\
\text { at the end of the word. }\end{array}$ & $\begin{array}{c}0 \\
(0 \%)\end{array}$ & $\begin{array}{c}8 \\
(3.7 \%)\end{array}$ & $\begin{array}{c}14 \\
(6.5 \%)\end{array}$ & $\begin{array}{c}151 \\
(69.6 \\
\%)\end{array}$ & $\begin{array}{c}44 \\
(20.3 \\
\%)\end{array}$ & $\begin{array}{c}4.06 \\
5\end{array}$ & $\begin{array}{c}0.64 \\
2\end{array}$ \\
\hline C9 & $\begin{array}{l}\dot{\varepsilon} \text { غ د، د، ل، د are the letters } \\
\text { which are related to Derlung } \\
\text { Rule. }\end{array}$ & $\begin{array}{c}0 \\
(0 \%)\end{array}$ & $\begin{array}{c}2 \\
(0.9 \%)\end{array}$ & $\begin{array}{c}12 \\
(5.5 \%)\end{array}$ & $\begin{array}{c}142 \\
(65.4 \\
\%)\end{array}$ & $\begin{array}{c}61 \\
(28.1 \\
\%)\end{array}$ & $\begin{array}{c}4.20 \\
7\end{array}$ & $\begin{array}{c}0.57 \\
6\end{array}$ \\
\hline C10 & $\begin{array}{l}\text { I display the pictures of 'chest } \\
\text { (dada)', 'net (jala)' and } \\
\text { 'ember (bara)' in the }\end{array}$ & $\begin{array}{c}1 \\
(0.5 \%)\end{array}$ & $\begin{array}{c}5 \\
(2.3 \%)\end{array}$ & $\begin{array}{c}19 \\
(8.8 \%)\end{array}$ & $\begin{array}{c}161 \\
(74.2 \\
\%)\end{array}$ & $\begin{array}{c}31 \\
(14.3 \\
\%)\end{array}$ & $\begin{array}{c}3.99 \\
5\end{array}$ & $\begin{array}{c}0.60 \\
5\end{array}$ \\
\hline
\end{tabular}


INTERNATIONAL JOURNAL OF ACADEMIC RESEARCH IN BUSINESS AND SOCIAL SCIENCES

Vol. 8, No. 12, Dec, 2018, E-ISSN: 2222-6990 @ 2018 HRMARS

\begin{tabular}{|c|c|c|c|c|c|c|c|c|}
\hline $\begin{array}{l}\text { Cod } \\
\text { e }\end{array}$ & Aspect/Item & SD & D & LA & A & SA & $\begin{array}{l}\text { MEA } \\
\mathbf{N}\end{array}$ & SD \\
\hline & 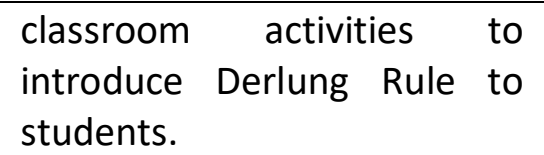 & & & & & & & \\
\hline C11 & $\begin{array}{l}\text { I label the pictures of 'chest } \\
\text { (dada)', 'net (jala)' and } \\
\text { 'ember (bara)' with بالا، دادارl. } \\
\text { and }\end{array}$ & $\begin{array}{c}0 \\
(0 \%)\end{array}$ & $\begin{array}{c}2 \\
(0.9 \%)\end{array}$ & $\begin{array}{c}13 \\
(6.0 \%)\end{array}$ & $\begin{array}{c}155 \\
(71.4 \\
\%)\end{array}$ & $\begin{array}{c}47 \\
(21.7 \\
\%)\end{array}$ & $\begin{array}{c}4.13 \\
8\end{array}$ & $\begin{array}{c}0.54 \\
4\end{array}$ \\
\hline C12 & $\begin{array}{l}\text { I explain to students that the } \\
\text { first syllable in Derlung Rule is } \\
\text { open syllable of vowel [a]. }\end{array}$ & $\begin{array}{c}1 \\
(0.5 \%)\end{array}$ & $\begin{array}{c}4 \\
(1.8 \%)\end{array}$ & $\begin{array}{l}26 \\
(12.0 \\
\%)\end{array}$ & $\begin{array}{c}162 \\
(74.7 \\
\%)\end{array}$ & $\begin{array}{c}24 \\
(11.1 \\
\%)\end{array}$ & $\begin{array}{c}3.94 \\
0\end{array}$ & $\begin{array}{c}0.58 \\
6\end{array}$ \\
\hline C13 & $\begin{array}{l}\text { Homograph } \\
\text { The word بيليق belongs to } \\
\text { Homograf. }\end{array}$ & $\begin{array}{c}5 \\
(2.3 \%)\end{array}$ & $\begin{array}{c}11 \\
(5.1 \%)\end{array}$ & $\begin{array}{c}23 \\
(10.6 \\
\%)\end{array}$ & $\begin{array}{c}142 \\
(65.4 \\
\%)\end{array}$ & $\begin{array}{c}36 \\
(16.6 \\
\%)\end{array}$ & $\begin{array}{c}3.88 \\
9\end{array}$ & $\begin{array}{c}0.82 \\
0\end{array}$ \\
\hline C14 & $\begin{array}{l}\text { Words with the same spelling } \\
\text { but different meaning are } \\
\text { classified as Homograph }\end{array}$ & $\begin{array}{c}0 \\
(0 \%)\end{array}$ & $\begin{array}{c}4 \\
(1.8 \%)\end{array}$ & $\begin{array}{c}19 \\
(8.8 \%)\end{array}$ & $\begin{array}{c}150 \\
(69.1 \\
\%)\end{array}$ & $\begin{array}{c}44 \\
(20.3 \\
\%)\end{array}$ & $\begin{array}{c}4.07 \\
8\end{array}$ & $\begin{array}{c}0.59 \\
9\end{array}$ \\
\hline C15 & $\begin{array}{l}\text { The words 'mahram' and } \\
\text { 'muharam'are spelled with } \\
\text { the same spelling. }\end{array}$ & $\begin{array}{c}6 \\
(1.8 \%)\end{array}$ & $\begin{array}{c}12 \\
(5.5 \%)\end{array}$ & $\begin{array}{c}15 \\
(6.9 \%)\end{array}$ & $\begin{array}{c}120 \\
(55.3 \\
\%)\end{array}$ & $\begin{array}{c}64 \\
(29.5 \\
\%)\end{array}$ & $\begin{array}{c}4.03 \\
2\end{array}$ & $\begin{array}{c}0.91 \\
5\end{array}$ \\
\hline C16 & $\begin{array}{l}\text { I identify the meaning of } \\
\text { every Homograph word } \\
\text { based on the context of the } \\
\text { sentence. }\end{array}$ & $\begin{array}{c}0 \\
(0 \%)\end{array}$ & $\begin{array}{c}2 \\
(0.9 \%)\end{array}$ & $\begin{array}{c}19 \\
(8.8 \%)\end{array}$ & $\begin{array}{c}151 \\
(69.9 \\
\%)\end{array}$ & $\begin{array}{c}45 \\
(20.7 \\
\%)\end{array}$ & $\begin{array}{c}4.10 \\
1\end{array}$ & $\begin{array}{c}0.56 \\
8\end{array}$ \\
\hline C17 & $\begin{array}{l}\text { I spell the words 'susuk' and } \\
\text { 'sosok' as سوسوق. }\end{array}$ & $\begin{array}{c}3 \\
(1.4 \%)\end{array}$ & $\begin{array}{c}3 \\
(1.4 \%)\end{array}$ & $\begin{array}{c}12 \\
(5.5 \%)\end{array}$ & $\begin{array}{c}139 \\
(64.1 \\
\%)\end{array}$ & $\begin{array}{c}60 \\
(27.6 \\
\%)\end{array}$ & $\begin{array}{c}4.15 \\
2\end{array}$ & $\begin{array}{c}0.70 \\
0\end{array}$ \\
\hline C18 & $\begin{array}{l}\text { I pronounce the word كون } \\
\text { displayed on the flash cards to } \\
\text { students as 'kun' and 'kon'. }\end{array}$ & $\begin{array}{c}7 \\
(3.2 \%)\end{array}$ & $\begin{array}{c}6 \\
(2.8 \%)\end{array}$ & $\begin{array}{c}11 \\
(5.1 \%)\end{array}$ & $\begin{array}{c}144 \\
(66.4 \\
\%)\end{array}$ & $\begin{array}{c}49 \\
(22.6 \\
\%)\end{array}$ & $\begin{array}{c}4.02 \\
3\end{array}$ & $\begin{array}{c}0.82 \\
5\end{array}$ \\
\hline C19 & $\begin{array}{l}\text { Numerical Method } \\
\text { Jawi script uses Arabic } \\
\text { numeral system. }\end{array}$ & $\begin{array}{c}48 \\
(22.1 \\
\%)\end{array}$ & $\begin{array}{c}39 \\
(18.0 \\
\%)\end{array}$ & $\begin{array}{c}30 \\
(13.8 \\
\%)\end{array}$ & $\begin{array}{c}79 \\
(36.4 \\
\%)\end{array}$ & $\begin{array}{c}21 \\
(9.7 \%)\end{array}$ & $\begin{array}{c}2.93 \\
6\end{array}$ & $\begin{array}{c}1.34 \\
9\end{array}$ \\
\hline C20 & $\begin{array}{l}\text { Arabic numbers are written } \\
\text { from the left to the right. }\end{array}$ & $\begin{array}{c}57 \\
(26.3 \\
\%)\end{array}$ & $\begin{array}{c}49 \\
(22.6 \\
\%)\end{array}$ & $\begin{array}{c}35 \\
(16.1 \\
\%)\end{array}$ & $\begin{array}{c}61 \\
(28.1 \\
\%)\end{array}$ & $\begin{array}{c}15 \\
(6.9 \%)\end{array}$ & $\begin{array}{c}2.66 \\
8\end{array}$ & $\begin{array}{c}1.31 \\
6\end{array}$ \\
\hline C21 & 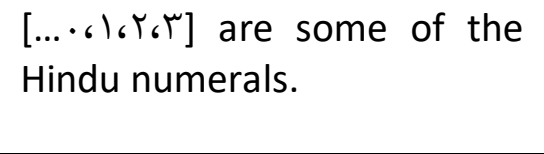 & $\begin{array}{c}63 \\
(29.0 \\
\%)\end{array}$ & $\begin{array}{c}47 \\
(21.7 \\
\%)\end{array}$ & $\begin{array}{c}36 \\
(16.6 \\
\%)\end{array}$ & $\begin{array}{c}64 \\
(29.5 \\
\%)\end{array}$ & $\begin{array}{c}7 \\
(3.2 \%)\end{array}$ & $\begin{array}{c}2.56 \\
2\end{array}$ & $\begin{array}{c}1.27 \\
2\end{array}$ \\
\hline
\end{tabular}


INTERNATIONAL JOURNAL OF ACADEMIC RESEARCH IN BUSINESS AND SOCIAL SCIENCES Vol. 8, No. 12, Dec, 2018, E-ISSN: 2222-6990 @ 2018 HRMARS

\begin{tabular}{|c|c|c|c|c|c|c|c|c|}
\hline $\begin{array}{l}\text { Cod } \\
\text { e }\end{array}$ & Aspect/Item & SD & D & LA & A & SA & $\begin{array}{l}\text { MEA } \\
\mathbf{N}\end{array}$ & SD \\
\hline $\mathrm{C} 22$ & $\begin{array}{l}\text { I write the date on the } \\
\text { blackboard as: } \\
2016 \text { جولاي } 26\end{array}$ & $\begin{array}{c}7 \\
(3.2 \%)\end{array}$ & $\begin{array}{c}10 \\
(4.6 \%)\end{array}$ & $\begin{array}{c}16 \\
(7.4 \%)\end{array}$ & $\begin{array}{c}142 \\
(65.4 \\
\%)\end{array}$ & $\begin{array}{c}42 \\
(19.4 \\
\%)\end{array}$ & $\begin{array}{c}3.93 \\
1\end{array}$ & $\begin{array}{c}0.86 \\
1\end{array}$ \\
\hline $\mathrm{C} 23$ & $\begin{array}{l}\text { I write the examination time } \\
\text { on the blackboard as: } \\
9.00-10.00\end{array}$ & $\begin{array}{c}9 \\
(4.1 \%)\end{array}$ & $\begin{array}{c}12 \\
(5.5 \%)\end{array}$ & $\begin{array}{c}16 \\
(7.4 \%)\end{array}$ & $\begin{array}{c}138 \\
(63.6 \\
\%)\end{array}$ & $\begin{array}{c}42 \\
(19.4 \\
\%)\end{array}$ & $\begin{array}{c}3.88 \\
5\end{array}$ & $\begin{array}{c}0.92 \\
3\end{array}$ \\
\hline C24 & $\begin{array}{l}\text { I correct the spelling of the } \\
\text { word راماما written by } \\
\text { students to رامامr. }\end{array}$ & $\begin{array}{c}1 \\
(0.5 \%)\end{array}$ & $\begin{array}{c}9 \\
(4.1 \%)\end{array}$ & $\begin{array}{c}16 \\
(7.4 \%)\end{array}$ & $\begin{array}{c}126 \\
(58.1 \\
\%)\end{array}$ & $\begin{array}{c}65 \\
(30.0 \\
\%)\end{array}$ & $\begin{array}{c}4.12 \\
9\end{array}$ & $\begin{array}{c}0.75 \\
3\end{array}$ \\
\hline \multicolumn{7}{|c|}{ Overall Value } & $\begin{array}{l}4.07 \\
4\end{array}$ & $\begin{array}{l}0.35 \\
0\end{array}$ \\
\hline
\end{tabular}

Although the overall finding of the analysis was at high level, there were four items which were $C 2, C 19, C 20$ and $C 21$ that obtained moderate mean value although the other 20 items obtained high mean value. Item C9 which was ' obtained the highest mean value (mean $=4.207$, $\mathrm{sd}=0.576)$. For this item, 61 respondents $(28.1 \%)$ answered 'strongly agree' and 142 respondents (65.4\%) answered 'agree' that the letters stated were related to Derlung Rule. However, 12 respondents (5.5\%) answered 'less agree' and the remaining 2 $(0.9 \%)$ 'disagree' with the statement. This finding indicated that most of the Islamic Studies teachers in Melaka Tengah district have strong knowledge of various Jawi script contained in Derlung Rule although there were a small number who have not mastered this topic well.

Item C17 which was 'I spell the words 'susuk' and 'sosok' as سوسوق' recorded the highest mean value (mean $=4.152$, sd=0.700). For this item, a total of 60 respondents $(27.6 \%)$ answered 'strongly agree' and 139 respondents (64.1\%) answered 'agree' while the remaining 16 answered 'less agree' , 'disagree' and 'strongly disagree' with this statement. Based on this finding, we could conclude that the Islamic Studies teachers in Melaka Tengah district have a good grasp of the concept of Homograph, which was the words with the same spelling but have different meaning.

The Islamic Studies teachers in Melaka Tengah district also have good understanding of numerical method in Jawi, which was the function of symbol [ $Y$ ] to symbolise double words. This could be seen through the analysis of item C24 'I correct the spelling of the wordten by students to راما' which obtained high mean value (mean $=4.129$, sd $=0.753$ ). Based on the analysis, 65 respondents (30.0\%) answered 'strongly agree' and 126 respondents (58.1\%) answered 'agree' that they used symbol [Y] when writing the word 'rama-rama' in Jawi. However, there were 16 respondents (7.4\%) who answered 'disagree' which indicated that there were still some respondents who did not understand very well on how to write double words in Jawi, which should be written using symbol $[r]$.

However, item C2 'the word ليوت cannot be categorised in _e / wa_method' obtained the lowest mean value (mean $=2.562$, $s d=1.272$ ) and was classified as moderate. Only 7 respondents 
INTERNATIONAL JOURNAL OF ACADEMIC RESEARCH IN BUSINESS AND SOCIAL SCIENCES

Vol. 8, No. 12, Dec, 2018, E-ISSN: 2222-6990 @ 2018 HRMARS

(3.2\%) answered 'strongly agree' and 64 respondents (29.5\%) answered 'agree' that this word could not be categorised in _e / wa_ method. While 36 respondents (16.6\%) answered 'less agree', 47 respondents (21.7\%) answered 'disagree' and the remaining 63 (29.0\%) answered 'strongly disagree'. 'ليوت' The answers from the respondents also indicated that some of them might translate the word mentioned in this item as 'lewat' not 'liut'. In conclusion, this analysis finding showed that the level of understanding of Islamic Studies teachers in Melaka Tengah district on _e / wa_ method was extremely low and a small number of respondents have understood the concept of adding 'alif' letter in that method.

\section{The Level of Understanding of Islamic Studies Teachers on CISS System}

The overall mean score for the understanding of Islamic Studies teachers in Melaka Tengah district on CJSS was high (mean $=2.696, \mathrm{sd}=0.461$ ). According to the mean score interpretation, 151 respondents (69.6\%) were in the category of 'high understanding' and the remaining 66 (30.4\%), were in 'moderate understanding' category while no respondents were in 'low understanding' category. The level of understanding of Islamic Studies teachers in Melaka Tengah district on CJSS was shown in Table 7.

Table 7: The Level of Understanding of Islamic Studies Teachers on CJSS

\begin{tabular}{llll}
\hline Mean Score & Frequency & Percentage & Mean Score Interpretation \\
\hline 1.00 to 2.33 & 0 & $0 \%$ & Low \\
2.34 to 3.66 & 66 & $30.4 \%$ & Medium \\
3.67 to 5.00 & 151 & $69.6 \%$ & High \\
Total & $\mathbf{2 1 7}$ & $\mathbf{1 0 0 \%}$ & \\
\hline
\end{tabular}

Overal Mean $=2.696$, Standard Deviation $=0.461$

The proficiency level of Islamic Studies teachers in Melaka Tengah district in changing the words into Jawi according to CJSS was shown in Table 8. Based on the analysis, 75 respondents (34.6\%) scored between 65\% -79\%, a 'good' grade score which was also the top grade score for the skill acquisition of changing the words into Jawi. 62 respondents (28.6\%) scored between $50 \%-64 \%$, which was 'satisfactory' and only 52 respondents (24.0\%) were 'excellent' which scored between $80 \%$ $-100 \%$. The total score for the three grades of 'satisfactory', 'good' and 'excellent' was 189 respondents $(87.1 \%)$ and they were categorised as 'proficient' in changing the words into Jawi using CJSS. 
INTERNATIONAL JOURNAL OF ACADEMIC RESEARCH IN BUSINESS AND SOCIAL SCIENCES

Vol. 8, No. 12, Dec, 2018, E-ISSN: 2222-6990 @ 2018 HRMARS

Table 8: The Proficiency Level of Writing Words in Jawi according to CJSS

\begin{tabular}{llcll}
\hline Marks & Frequency & Percentage & Grade & Grade Score Interpretation \\
\hline $0-39$ & 7 & $3.2 \%$ & Very Poor & Not proficient \\
Total & $\mathbf{7}$ & $\mathbf{3 . 2 \%}$ & & \\
40 - 49 & 21 & $9.7 \%$ & Poor & Proficient at minimum level \\
Total & $\mathbf{2 1}$ & $\mathbf{9 . 7 \%}$ & & \\
$50-64$ & 62 & $28.6 \%$ & Satisfied & \\
$65-79$ & 75 & $34.6 \%$ & Good & Proficient \\
$80-100$ & 52 & $24.0 \%$ & Excellent & \\
Overall & $\mathbf{1 8 9}$ & $\mathbf{8 7 . 1 \%}$ & & \\
& $\mathbf{2 1 7}$ & $\mathbf{1 0 0 \%}$ & & \\
\hline
\end{tabular}

However, the analysis of this study also scored relatively high for 'poor' grade which was 21 respondents (9.7\%) who obtained marks between $40 \%-49 \%$, whereas the remaining 7 respondents (3.2\%) were 'very weak', who scored between $0 \%-39 \%$. Overall, the analysis showed that the total score for the 'poor' grade was categorised as 'mastering minimum level' and 'very poor' grade was categorised as 'not proficient' for changing the words into Jawi according to CJSS. The finding concluded that there were small number of respondents who taught Jawi lessons but have not mastered Jawi skills well using CJSS.

\section{DISCUSSION}

Every teacher should have profound knowledge more than their students. Their knowledge and proficiency especially the subjects they taught must be intense to convince themselves and gain the trust from the students (Jaafar, Tamuri \& Ya, 2012) in order to be respected by them (Tamuri, Ismail \& Jasmi, 2012). Thus, for this study, profound knowledge that should be acquired by the teachers in teaching Jawi was concerned with the Complete Jawi Spelling System (CJSS) as instructed by the Ministry of Education through Circular Letter No. 1/1992. To achieve good and effective Jawi teaching practices, Islamic Studies teachers must have high level of knowledge about CJSS and be able to master the skills of CJSS comprehensively.

Derlung Rule was one of the methods contained in CJSS that should be acquired by the Islamic Studies teachers. Based on the analysis, this study showed that most of the Islamic Studies teachers in Melaka Tengah district have great knowledge of the letters that were categorized in Derlung Rule. This finding was in line with the statement of Tamuri, Ismail and Jasmi (2012) who stated that a teacher should have wide knowledge, including in-depth knowledge of the subjects they taught. The Islamic Studies teachers in Melaka Tengah district seemed to clearly understand the concept of Derlung Rule which was the method related to two open syllables at the end of the words (Abdul Rahman, 2014; Hamzah, Lubis \& Che Noh, 2016) when they obtained high mean score on items related to this construct. This finding demonstrated that the Islamic Studies teachers in Melaka Tengah district have mastered the contents of the subjects taught very well and they have great skills in spelling Jawi correctly for Derlung Rule, hence criticized the finding of Ali (2012) which stated that the teachers' proficiency level in Jawi reading and writing was moderate. 
However, the level of understanding of Islamic Studies teachers was not only measured in terms of their knowledge in Jawi which was their field, but they must also be knowledgeable on how to teach or convey knowledge. The process of delivering knowledge to students was something very important (Nor \& Mahamod, 2014), as the teachers who were knowledgeable but failed to deliver knowledge were categorized as a 'failed' teacher. The Islamic Studies teachers must ensure that their personality was not only in terms of the content mastery of Jawi lessons, but also from the aspect of pedagogical content as the content mastery of teacher's pedagogy in Jawi would determine the quality of their teaching practices and thus, affect the students. However, knowledge in Jawi and how to deliver that knowledge were not enough if the teachers themselves did not have Jawi reading and writing skills according to CJSS.

Thus, based on this study, the proficiency of CJSS in terms of skills could be seen through the knowledge and skills acquired by the Islamic Studies teachers in Melaka Tengah district where Homograph seemed to be a method that often confused the users (Abdul Aziz \& Musa, 2010). Based on the finding, it could be understood that the Islamic Studies teachers in Melaka Tengah district have understood better on the concept of Homograph in Jawi when they agreed that the words 'susuk' and 'sosok' should be spelled similarly in Jawi. This corresponded with the definition of homograph that refers to words which have different meaning but are spelled with the same spelling (Ahmad 2015; Abdul Rahman, 2014). This finding demonstrated that the Islamic Studies teachers in Melaka Tengah district have not only had deep knowledge on Homograph concept but also acquired skills in spelling and writing Homograph words according to proper CJSS. The combination of these two elements of content knowledge and writing skills will lead to the acquisition of pedagogical content, which was an effective Jawi teaching.

However, to master Jawi reading and writing skills according to CJSS was not easy and the challenges were not only faced by the non-Islamic Studies teachers but also most of the Islamic Studies teachers. This statement was proven by the finding of numerical method construct, which obtained mean value lower than other constructs and it was only at a moderate level. This finding suggested that the understanding of Islamic Studies teachers in Melaka tengah district on the numerical method in Jawi was low and they did not know that the numbers [... $\cdot$ I $_{6} \mathrm{Y}_{6} \mathrm{Y}$ ] $]$ were actually Hindu numerals and not the Arabic numerals (Ahmad, 2015). This scenario should not happen to Islamic Studies teachers who should master each Jawi content well, especially if the numerical method was the most basic knowledge that should have been acquired by them. This finding seemed to be related with the finding by Ali \& Abdullah (2015) which stated that the Islamic Studies teachers did not have a solid foundation on CJSS due to lack of exposure as Jawi was not taught specifically when they were in the faculty of Islamic Studies.

Lack of strong fundamental knowledge on CJSS was proven by the finding, which showed that $3.2 \%$ of Islamic Studies teachers in Melaka Tengah district did not master the skills yet based on the test of changing the words into Jawi that followed the exact CJSS. Although this percentage was relatively small, the finding illustrated that there was still a small number of Islamic Studies teachers 
in Melaka Tengah district who have taught Jawi but still have not mastered CJSS properly. This finding was consistent with studies by Ali (2011 \& 2012), Abdullah (2014) and Bahrun (2011) who found that the proficiency level of Jawi spelling of teachers-to-be was moderate. The weaknesses in acquiring and mastering Jawi spelling and writing skills through CJSS would undoubtedly lead to mistakes in the lessons delivered to the students. This statement was reinforced by Ahmad (2015) who stated that to date, the Islamic Studies teachers and certain books have taught students that there were only three vowels in Jawi, while in fact there were four Jawi vowels, which were alif, wau, ya' and 'ye that should be taught since 2005 when the General Guidelines of Malay Jawi Spelling (PUEJBM) was launched by the Dewan Bahasa and Pustaka. Therefore, the Islamic Studies teachers should always cultivate the knowledge within themselves (Jaafar, Tamuri \& Ya, 2012) to address these shortcomings.

\section{CONCLUSION}

The Islamic Studies teachers who are effective in the teaching of Jawi are the teachers who are always trying to prepare themselves with knowledge and skills using CJSS from time to time and think globally to find information continuously as a process of acquiring knowledge to ensure the transmission of accurate knowledge and facts to their students. Through the integration of in-depth knowledge on the content of the lessons and skill acquisition using CJSS in Jawi writing, teachers will be able to produce an effective teaching that will facilitate students to master Jawi reading and writing more quickly and effectively. Excellent Jawi proficiency among students will help them understand and acquire the knowledge of Islamic Studies better as Islamic Studies subject is supposed to be taught entirely in Jawi. The teachers who teach Jawi will also indirectly contribute to the formation of a society who respects the Jawi script as a precious art heritage.

\section{Acknowledgement}

The authors hereby acknowledge the Universiti Teknologi Malaysia for their financial support through the Grant no. R.J130000.7831.4F950.

\section{Corresponding Author}

Naquiah Nahar, Academy of Islamic Civilization, Faculty of Social Science and Humanities, Universiti Teknologi Malaysia, Malaysia.

Email: naquiah2@live.utm.my

\section{References}

Abd Hamid, F. \& Abdullah, N. (2009). Penguasaan tulisan Jawi di kalangan mahawiswa Pengajian Islam: kajian di Institut Pengajian Tinggi Awam (IPTA) Tempatan (The mastery of the Jawi writings among Islamic Studies students: studies at the Local Institutes of Higher Learning (IPTA). Al-Tamaddun Journal, No. 4 (2009) 145-156.

Abdul Aziz, A. \& Musa, H. (2010). Isu Homograf dan cabarannya dalam usaha pelestarian tulisan Jawi (Homograph issues and challenges in the effort to preserve the Jawi script). Aswara Journal. $3(1 / 2008), 109-125$. 
INTERNATIONAL JOURNAL OF ACADEMIC RESEARCH IN BUSINESS AND SOCIAL SCIENCES

Vol. 8, No. 12, Dec, 2018, E-ISSN: 2222-6990 @ 2018 HRMARS

Abdullah, N. (2014). Penguasaan dan Penggunaan Tulisan Jawi dalam Pembelajaran: Kajian di Kalangan Guru Pelatih Pendidikan Islam, Institut Pendidikan Guru Malaysia, Kuala Lumpur (Mastery and Use of Jawi Writings in Learning: Study among Teachers of Islamic Education Trainers, Institute of Teacher Education Malaysia, Kuala Lumpur). Dissertation of Graduate Usuluddin, Faculty of Usuluddin. Kuala Lumpur: University of Malaya.

Abdul Rahman, H. (2014). Panduan menulis dan mengeja Jawi (Guide to writing and spelling Jawi). Kuala Lumpur: Dewan Bahasa dan Pustaka.

Ahmad, A. (2015). Kaedah Pembelajaran Jawi (Jawi Learning Methods). Kuala Lumpur: National Library of Malaysia.

Ali, A.R. (2011). Pola-Pola Kesalahan Ejaan Jawi dalam Kalangan Guru Pelatih JQAF Ambilan 2011 (Jawi Spelling Mistakes Patterns in Teacher Training JQAF Intake 2011). Proceedings of the Eastern Zone Research Seminar. Besut: IPG Sultan Mizan Campus. 10-12 May 2011.

Ali, A.R. (2012). Cabaran Program Pemulihan Jawi j-QAF dalam Memperkasakan Tranformasi Ejaan Jawi Yang Disempurnakan (The j-QAF Jawi Recovery Program Challenge in Empowering Enhanced Jawi Spelling Transformation). Proceedings of the Malay Jawi And Malay Manuscript Seminar 2012. Shah Alam: Center for Islamic Thought and Understanding, UiTM. 19-20 June 2012.

Ali, A.R. \& Abdullah, B. (2015). Falsafah Pendidikan Jawi dalam memperkasakan tamadun Islam di Malaysia (Jawi Education philosophy in empowering Islamic civilization in Malaysia). Proceedings of ICIC2015-International Conference on Empowering Islamic Civilization in the $21^{\text {st }}$ Century. Malaysia: Sultan Zainal Abidin University, 6-7 September 2015. 574-585.

Bahrun, S. (2011). Perkembangan Tulisan Jawi di Malaysia (The development of Jawi script in Malaysia). Proceedings of the Borneo International Conference. Indonesia: University of Mulawarman.

Che Man, C.S. (2007). Pendekatan Pengajaran Jawi (Jawi Teaching Approach). Kuala Lumpur: Dewan Bahasa dan Pustaka.

George, D. \& Mallery, P. (2006). SPSS for Windows Step by Step: A Simple Guide \& Reference. India: Pearson Education, Inc.

Hamzah, H.; Lubis, M. A. \& Che Noh, M. A. (2016). Penggunaan kaedah mnemonik meningkatkan kemahiran menentukan kedudukan huruf "alif" dalam penulisan Jawi (The use of mnemonic methods increases the ability to determine the position of the "alif" in the writing of Jawi). 
INTERNATIONAL JOURNAL OF ACADEMIC RESEARCH IN BUSINESS AND SOCIAL SCIENCES

Vol. 8, No. 12, Dec, 2018, E-ISSN: $2222-6990$ C 2018 HRMARS

Islamic Education Discourse of the 11th Series. Bangi: Malaysian Islamic Training Institute. 15 - 16 November 2016.

Haron, I. (2008). Keberkesanan kaedah gabungan bunyi kata (KGBK) dalam pengajaran Jawi peringkat awal dan pemulihan (The effectiveness of the combination of word sound (KGBK) in early Jawi teaching and recovery). National Seminar on Writing Jawi Writing and Translation, Tanjung Malim: Sultan Idris Education University, p.3.

Hashim, Z. \& Phang, F.A. (2013). Amalan Pengetahuan Teknologi Pedagogi Kandungan Guru Fizik Tingkatan Enam (Pedagogy Technology Knowledge of Form Six Physics Teacher). Master Thesis, Johor Bahru: University of Technology Malaysia.

Jaafar, M.M., Tamuri, A.H., \& Ya, R. (2012). Konsep Berilmu di Kalangan Guru Pendidikan Islam Satu Keperluan dalam Membangunkan Modal Insan (The Knowledge Concept Among Teachers of Islamic Education One Needs in Developing Human Capital). International Seminar on Islamic Education and Education [SEAPPI2012] at Le Grandeur Palm Resort, Senai, Johor Bahru on 89 March 2012, pp. 289-303.

Jemali, M. (2008). Tahap Penguasaan Jawi Baru Kalangan Pelajar Siswazah Pengajian Islam (Level of New Jawi Proficiency of Graduate Students of Islamic Studies). National Seminar on Writing Jawi Writing and Translation. Tanjung Malim: Sultan Idris Education University, p. 3.

Krejcie, R.V. \& Morgan, D.W. (1970). Determining sample size for research activities. Educational \& Psychological Measurement, 30, 607-610.

Ministry of Education Malaysia. (2003). Circular Letter No.5/2003:Pelaksanaan Kurikulum Semakan Pendidikan Islam dan Bahasa Arab (Implementation of Islamic and Arabic Education Review Curriculum).

Mohamad, M. (2007). Penguasaan kemahiran Jawi di kalangan murid Tingkatan Dua di Sekolah Menengah Kebangsaan di Wilayah Persekutuan Kuala Lumpur (The mastery of Jawi skills among Form Two students in Sekolah Menengah Kebangsaan in the Federal Territory of Kuala Lumpur). Dissertation (M.Ed.), Faculty of Education, Kuala Lumpur: Universiti Malaya.

Mohd Hassan Abdullah, N.; Siraj, S.; Hussin, Z. \& Alias, N. (2010). Isu kritikal penggunaan tulisan Jawi dalam pelaksanaan kurikulum Pendidikan Islam peringkat sekolah menengah: Pandangan pakar (Critical issue of Jawi writing in the implementation of the Islamic Education curriculum at the secondary level: Experts view). Education Journal, 30, 63-84.

Mohamad @ Mohd Noor, N. (2013). Penggunaan modul pembelajaran kemahiran Jawi (The use of Jawi skills learning modules). Master Thesis, Johor Bahru: University of Technology Malaysia. 
INTERNATIONAL JOURNAL OF ACADEMIC RESEARCH IN BUSINESS AND SOCIAL SCIENCES

Vol. 8, No. 12, Dec, 2018, E-ISSN: $2222-6990$ C 2018 HRMARS

Nik Yaacob, N.R. (2007). Penguasaan Jawi dan hubungannya dengan minat dan pencapaian pelajar dalam Pendidikan Islam (Jawi domination and its relationship with the interests and achievement of students in Islamic Education). Journal of Educators and Islamic Education, Vol. 22, 161-172.

Nor, M. \& Mahamod, Z. (2014). Pengetahuan pedagogi kandungan guru bahasa Iban yang baharu dengan yang berpengalaman di sekolah-sekolah menengah di Sarawak (The pedagogical knowledge of new Iban language teachers with experienced in secondary schools in Sarawak). Malaysian Journal of Learning and Instruction. Vol. 11(2014), 2017-236.

Nor, M. \& Mahamod, Z. (2014). Penterjemahan Pengetahuan Pedagogi Kandungan dalam Proses Tindakan Guru Bahasa Iban Baharu dan Berpengalaman Bukan Opsyen (The Application of the Pedagogical Content Knowledge Among not an Opstion New and Experienced Iban Language Teachers). Malaysian Education Journal. 39(1)(2014): 37-49.

Suhid, A.; Abu Bakar, K.; Abdul Mutalib, L. \& Muhammad, M.F. (2008). Teacher's perception towards the model of Jawi writing in Malaysian education system. The International Journal of Interdisciplinary Social Sciences, 3(5) 47-52.

Syarifuddin, N.S \& Halim, L. (2017). Amalan Pengetahuan Pedagogi Isi Kandungan Guru Baharu (Pedagogical Knowledge Practice Content of Novice Teacher). Bangi: National Universiti of Malaysia, 682-690. https://www.wordpress.com. Retrieved on 21 May 2017.

Tamuri, A.H.; Ismail, M.F \& Jasmi, K.A. (2012). Komponen asas untuk latihan Guru Pendidikan Islam (The basic component for the training of Islamic Education Teachers). Global Journal al Thaqafah, 2(2), 53-63. 